Giovannetti, S., and Pasero, G. (1959). Minerva nefrol., 6, 119.

Hodgkinson, A. (1962). Clin. Sci., 23, 203

Huth, E. J., Webster, G. D., and Elkinton, J. R. (1960). Amer. F. Med., 29,586 .

Jackson, W. P. U., and Linder, G. C. (1953). Quart. F. Med., 22, 133.

Kaitz, A. L. (1961). F. clin. Invest., 40, 1331 .

Kleeman, C. R., Hewitt, W. L., and Guze, L. B. (1960). Medicine (Baltimore), 39,3

Latner, A. L., and Burnard, E. D. (1950). Quart. F. Med., 19, 285.

Lathem, W. (1958). New Engl. F. Med., 258, 1031.

Lemann, J., Litzow, J. R., and Lennon, E. J. (1967). F. clin. Invest., 46, 1318 .

Little, P. J., and de Wardener, H. E. (1962). Lancet, 1, 1145.

McCance, R. A., Matheson, W. J., Gresham, G. A., and Elkinton, J. R. (1960). Arch. Dis. Childh., 35, 240.

Miles, B. E., Paton, A., and de Wardener, H. E. (1954). Brit. med. F., 2, 901 .

Milne, M. D. (1951). The Action of Parathyroid Hormone and the Metabolic Changes Following Mobilization of Bone Salt. Thesis, University of Manchester.

Morrin, P. A. F. (1965). Metabolism, 14, 674.

Nordin, B. E. C., and Bulusu, L. (1968). Postgrad. med. 7., 44, 93.
Nordin, B. E. C., Hodgkinson, A., and Peacock, M. (1967). Clin. Orthop., 52, 293.

Nordin, B. E. C., and Smith, D. A. (1963). Brit. F. Urol., 35, 438.

Nordin, B. E. C., and Smith, D. A. (1965). Diagnostic Procedures in Disorders of Calcium Metabolism. London.

Nordin, B. E. C., and Smith, D. A. (1967). In L'Osteomalacie, edited by D. J. Hioco. Paris.

Peacock, M., and Nordin, B. E. C. (1968). f. clin. Path. In press.

Pitts, H. H., jun., Schulte, J. W., and Smith, D. R. (1955). F. Urol. (Baltimore), 73, 208.

Rapoport, A., Crassweller, P. O., Husdan, H., From, G. L. A., Zweig, M., and Johnson, M. D. (1967). Metabolism, 16, 176.

Riddick, F. A., and Reiss, E. (1962). Ann. intern. Med., 56, 183.

Robertson, W. G., Peacock, M., and Nordin, B. E. C. (1968). Clin. Sci. In press.

Schwartz, W. B., and Relman, A. S. (1957). New Engl. F. Med., 256 , 1184 .

Shields, R. (1966). In Postgraduate Gastro-Enterology, edited by R. J. Thomson and I. G. Gillespie. London.

Wootton, I. D. P., and King, E. J. (1953). Lancet, 1, 470.

Wrong, $\mathrm{O}$ (1965) $\%$ clin Path $18,520$.

Wrong, O., and Davies, I. E. F.'(1959). Quart. F. Med., 28, 259.

\title{
Effect of Calcium Administration and Deprivation on Serum and Urine Calcium in Stone-forming and Control Subjects
}

\author{
M. PEACOCK,* M.B., CH.B., M.R.C.P. ; F. KNOWLES,* F.I.M.L.T. ; B. E. C. NORDIN,* M.D., PH.D., F.R.C.P.
}

Brit. med. F., 1968, 2. 729-731

Idiopathic hypercalciuria is a syndrome characterized by a raised urinary calcium associated with normocalcaemia and a tendency to hypophosphataemia (Albright et al., 1953; Harrison, 1959 ; Edwards and Hodgkinson, 1965). Hypercalciuria is common in patients with renal stone disease (Flocks, 1939 ; Hodgkinson and Pyrah, 1958), but is also present in a proportion of the normal population (Knapp, 1947 ; Hodgkinson and Pyrah, 1958; Watson and Dale, 1966; Nordin et al., 1967), the exact prevalence depending on how it is defined.

The cause of idiopathic hypercalciuria has not been established, but increased calcium absorption is known to be a feature of the condition (Henneman et al., 1958 ; Hodgkinson, 1961). Some workers believe this hyperabsorption of calcium to be primary, while others regard it as a response to increased calcium excretion (Jackson and Dancaster, 1959). In previous papers we have shown that tubular reabsorption of calcium is generally normal in idiopathic hypercalciuria (Nordin et al., 1967 ; Peacock and Nordin, 1968). The present paper gives further data on the relation between calcium ingested, plasma calcium, and urinary calcium in normal and hypercalciuric subjects and describes a simple prucedure for the diagnosis of the condition.

\section{Clinical Material and Methods}

The patients consisted of nine male idiopathic renal stoneformers who showed persistent hypercalciuria on a free diet according to the definition of Hodgkinson and Pyrah (1958)that is, over $300 \mathrm{mg}$. daily. Their ages ranged from 24 to 54 years. In no case was there evidence of renal failure, systemic acidosis, or endocrine disease. The controls consisted of nine healthy males, all members of staff, aged 17 to 40 years, none of whom was hypercalciuric.

The hypercalciuric patients were first studied in the nonfasting state when simultaneous samples of blood and urine were obtained for measurement of calcium and creatinine. Subsequently the patients were admitted to the ward fasting and observed for one day of total starvation. Tap-water was given at a rate of half a pint $(285 \mathrm{ml}$.) an hour to ensure adequate urine flow and bladder emptying. Urine samples were collected every two hours and blood was taken at the midpoint of each collection. The test usually started at 8 a.m. and was completed by 6 p.m. On another day the same patients were again admitted to the ward after an overnight fast. A two-hour specimen of urine was collected with a blood sample taken at the midpoint and the patients were then given an oral load of calcium (100 mg. $/ \mathrm{kg}$.) as a calcium citrate suspension over a period of 15 minutes. Urine samples were collected for eight hours, hourly for the first four hours and two-hourly thereafter. Blood samples were taken at the midpoint of each urine collection. A light calcium-free breakfast was allowed half an hour after the calcium load and a light low-calcium lunch three hours later. The patients were not confined to bed. The calcium citrate was well tolerated by all of them and did not cause vomiting or diarrhoea.

In the nine controls blood and urine samples were obtained after an overnight fast for comparison with the stone cases, and the calcium citrate load was given and samples were obtained as described for the nine cases of idiopathic hypercalciuria.

Calcium was estimated with $o$-cresolphthalein complexone in serum and urine by AutoAnalyzer techniques as modified by Knowles (1968). Creatinine was estimated with picric acid by the standard AutoAnalyzer method (Technicon Methods Manual, N-11b).

Urine calcium is expressed as calcium excreted per $100 \mathrm{ml}$. of glomerular filtrate $\left(\mathrm{Ca}_{\mathrm{E}}\right)$, which is calculated as follows (Nordin et al., 1967 ; Peacock and Nordin, 1968):

$\mathrm{Ca}_{\mathrm{E}}$ (mg. $/ 100 \mathrm{ml}$. of G.F.) = urine calcium $\times$ plasma creatinine when all concentrations are expressed in $\mathrm{mg} . / 100 \mathrm{ml}$. The range of plasma creatinine was the same in stone-formers and controls (0.7-1.1 mg./100 ml.).

* Medical Research Council, Mineral Metabolism Research Unit, the General Infirmary, Leeds. 


\section{Results}

In the control cases the mean fasting serum calcium was $9.51 \pm 0.063 \mathrm{mg} . / 100 \mathrm{ml}$. and the mean fasting urine calcium was $0.077 \pm 0.016 \mathrm{mg} . / 100 \mathrm{ml}$. of glomerular filtrate (Table I and Fig. 1).

In the hypercalciuric stone-formers the mean outpatient nonfasting serum calcium was $10.17 \pm 0.13 \mathrm{mg} . / 100 \mathrm{ml}$. and the urine calcium $0.30 \pm 0.027 \mathrm{mg} . / 100 \mathrm{ml}$. of glomerular filtrare (Table II and Fig. 2). Both these values are significantly higher than the fasting normal values $(\mathrm{P}<0.001)$. Fasting overnight reduced these non-fasting values to $9.84 \pm 0.18$ and $0.15 \pm 0.015$ respectively. The fall in serum calcium is not significant, but the fall in urine calcium is $(\mathrm{P}<0.001)$ (Fig. 2 and Table II). The fasting values are still significantly higher than the fasting normal values, but only just $(\mathrm{P}<0.05)$.

TABLE I.-Serum and Urine Calcium in Control Subjects and Hypercalciuric Stone-formers Fasting and Three and a Half Hours After an Oral Dose of Calcium Citrate (100 mg. Calcium/kg.)

\begin{tabular}{|c|c|c|c|c|c|c|c|c|}
\hline & \multicolumn{4}{|c|}{ Serum Ca (mg./100 ml. \pm S.E.) } & \multicolumn{4}{|c|}{ Urine $\mathrm{Ca}(\mathrm{mg} / 100 \mathrm{ml}$. of G.F. \pm S.E. $)$} \\
\hline & Fasting & $3 \frac{1}{2}$ Hours after Load & “ $t "$ & $p$ & Fasting & 3-4 Hours after Load & " $t "$ & $p$ \\
\hline 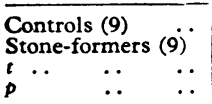 & $\begin{array}{c}9.51 \pm 0.063 \\
9.83 \pm 0.12 \\
2.45 \\
<0.05\end{array}$ & $\begin{array}{c}10.13 \pm 0.12 \\
10.90 \pm 0.18 \\
3.49 \\
<0.01\end{array}$ & $\begin{array}{l}4.55 \\
4.92\end{array}$ & $\begin{array}{l}<0.001 \\
<0.001\end{array}$ & $\begin{array}{c}0.077 \pm 0.016 \\
0.13 \pm 0.020 \\
2.18 \\
<0.05\end{array}$ & $\begin{array}{c}0.26 \pm 0.032 \\
0.51 \pm 0.055 \\
3.92 \\
<0.01\end{array}$ & $\begin{array}{l}5 \cdot 21 \\
6 \cdot 49\end{array}$ & $\begin{array}{l}<0.001 \\
<0.001\end{array}$ \\
\hline
\end{tabular}
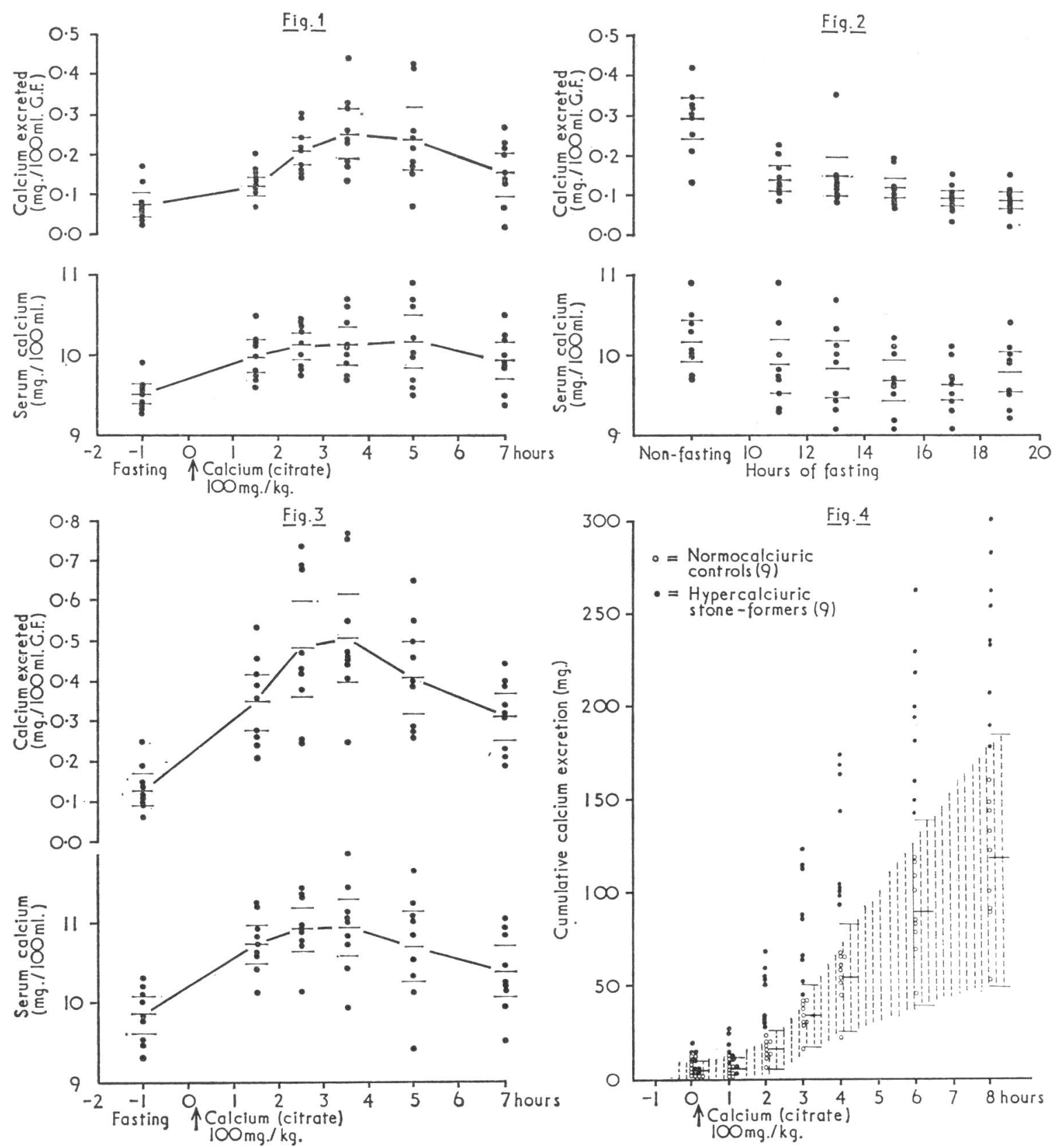

Fig. 1.-Serum and urint calcium in nine normocalciuric control subiects after overnight fasting and after administration of an oral load of calcium citrate (mean values +2 S.E.). FIG. 2. - Serum and urine calcium in nine cases of hypercalciuric stone disease, non-fasting (left) and during prolonged calcium deprivation (mean values \pm 2 S.E.). Fig. 3.-Serum and urine stone disease, non-fasting (left) and during prolonged calcium deprivation (mean values \pm 2 S. E.). FIG. 3. - Serum and urine
calcium in nine patients with hypercalcuuric stone disease fasting and after an oral dose of calcium citrate (mean values \pm 2 calcium in nine patients with hypercalcuric stone disease fasting and after an oral dose of calcium citrate (mean values \pm 2
S.E). FIG. 4.-Cumulative caicium excretion in nine normoualciuric control subjects and nine patients with hypercalciuric stone disease after an oral dose of calcium citrate (mean values \pm 2 S.D). 
Fasting for a further six hours, however, reduced the mean serum and urine calcium values to levels which were not significantly higher than the normal fasting values.

The effect of the oral calcium load on serum and urine calcium in the control subjects is shown in Fig. 1. The mean serum calcium rose from 9.51 to $10.13 \mathrm{mg} . / 100 \mathrm{ml}$. by three and a half hours, after which it remained steady for a further two to three hours. The mean urine calcium rose from 0.077 $\mathrm{mg} . / 100 \mathrm{ml}$. of glomerular filtrate to 0.26 at three to four hours, and was falling with the serum calcium at seven hours.

TABLE II.-Serum and Urine Calcium in Hypercalciuric Stone-formers Before and During Prolonged Fasting

\begin{tabular}{|c|c|c|c|c|c|c|}
\hline & \multicolumn{3}{|c|}{$\begin{array}{c}\text { Serum Ca } \\
\text { (mg./100 ml. } \pm \text { S.E.) }\end{array}$} & \multicolumn{3}{|c|}{$\begin{array}{l}\text { Urine Ca } \\
\text { (mg./100 ml. of G.F. } \pm \text { S.E.) }\end{array}$} \\
\hline & & “ $t$ " & $p$ & & " $t "$ & $p$ \\
\hline $\begin{array}{l}\text { Non-fasting } \\
\text { Fasting }\end{array}$ & $10 \cdot 17 \pm 0 \cdot 13$ & & & $0.30 \pm 0.027$ & & \\
\hline $\begin{array}{l}10 \text { hours } \\
16 \text { hours }\end{array}$ & $\begin{array}{l}9 \cdot 84 \pm 0 \cdot 18 \\
9 \cdot 60 \pm 0.11\end{array}$ & $\begin{array}{l}1 \cdot 47 \\
3 \cdot 35\end{array}$ & $\begin{array}{l}<0.2 \\
<0.01\end{array}$ & $\begin{array}{l}0.15 \pm 0.015 \\
0.096 \pm 0.012\end{array}$ & $\begin{array}{l}4 \cdot 78 \\
6 \cdot 74\end{array}$ & $\begin{array}{l}<0.001 \\
<0.001\end{array}$ \\
\hline
\end{tabular}

In the hypercalciuric cases the calcium load raised the serum and urine calcium more rapidly and to a higher level than in the controls (Fig. 3). The mean peak serum calcium was $10.90 \mathrm{mg} . / 100 \mathrm{ml}$. and the mean peak urine calcium $0.51 \mathrm{mg} . /$ $100 \mathrm{ml}$. of glomerular filtrate. Both these peak values are significantly higher than the corresponding values in the controls $(\mathrm{P}<0.01$ ) (Table I).

In both groups the rise in serum and urine calcium produced by the oral load was highly significant $(P<0.001)$ (Table I).

The cumulative absolute calcium excretion after the oral calcium load in both groups is shown in Fig. 4. The basal urine calcium excretion tended to be higher in the hypercalciurics than in the control cases, but the overlap was considerable. After two hours there was an absolute separation of the two groups and the difference between them became progressively greater with time.

After eight hours all the hypercalciurics had excreted over $174 \mathrm{mg}$. of calcium and all the controls less than this.

\section{Discussion}

We have shown that in idiopathic male stone-formers with hypercalciuria calcium excretion is increased in the non-fasting state but generally falls to normal after an overnight fast. In those cases in which it remains raised, further fasting for six to eight hours almost invariably brings the urine calcium into the normal range. The non-fasting serum calcium tends to be at the upper limit of normal but falls to normal with calcium deprivation, generally to less than $10 \mathrm{mg} . / 100 \mathrm{ml}$. In only one of our cases did the urine calcium remain high after 24 hours of calcium deprivation. Thus differences in the severity of calcium deprivation may explain in part the conflicting results obtained by previous workers. Some have reported that urinary calcium falls to normal on a low calcium diet (Henneman et al., 1958 ; Harrison, 1959 ; Gill and Bartter, 1961 ; Peacock et al., 1967), while others record that urinary calcium remains high (Jackson and Dancaster, 1959 ; Edwards and Hodgkinson, 1965; Phillips and Cooke, 1967).

It will be noted that urinary calcium after the standard calcium load was higher in the stone-formers than in the controls whether it was expressed in absolute terms or in units per $100 \mathrm{ml}$. of glomerular filtrate. This excludes the remote possi- bility that idiopathic hypercalciuria might be an artifact occurring in subjects with an exceptionally high glomerular filtration rate. In general, as we have discussed elsewhere (Nordin et al., 1967), we advocate for most purposes that calcium excretion be expressed in $\mathrm{mg} . / 100 \mathrm{ml}$. of glomerular filtrate, since this eliminates differences in calcium output due to glomerular function per se.

Our results suggest that this form of hypercalciuria is generally due to hyperabsorption, as Caniggia et al. (1965) have claimed. This is borne out by the response to oral calcium. In normal subjects there is a measurable and significant rise in serum calcium, which reaches its peak at three to four hours, and a corresponding rise in urine calcium, presumably due to the increase in filtered load. Subjects with idiopathic hypercalciuria show a similar response, but their blood and urine values rise to a significantly higher level. This procedure may be used to distinguish subjects with absorptive hypercalciuria from normocalciuric individuals, and in view of the great variation in urine calcium of hypercalciuric persons on a free diet this may be a better way of identifying hypercalciuria than an outpatient 24-hour collection.

\section{Summary}

In nine hypercalciuric patients with renal stone disease nonfasting serum and urine calcium were significantly raised. After overnight fasting, both serum and urine calcium values had fallen almost into the normal range and calcium deprivation for a further eight hours yielded completely normal values in all but one case.

Oral administration of a large dose of calcium citrate (100 mg. calcium $/ \mathrm{kg}$.) produced a significant rise in serum and urine calcium in both groups, but the rise was significantly greater in the hypercalciuric subjects than in the controls.

The cumulative eight-hour calcium excretion after the oral load was more than $174 \mathrm{mg}$. in all the hypercalciuric cases and less than this amount in the controls.

These observations tend to show that idiopathic hypercalciuria is absorptive in origin and emphasize the importance of measuring serum and urine calcium in the fasting state. It is suggested that oral calcium loading may constitute a better diagnostic test of this condition than a 24-hour urine collection on a free diet.

\section{REFERENCES}

Albright, F., Henneman, P., Benedict, P. H., and Forbes, A. P. (1953) f. clin. Endocr., 13, 860.

Caniggia, A., Gennari, C., and Cesari, L. (1965). Brit. med. 7., 1, 427.

Edwards, N. A., and Hodgkinson. A. (1965). Clin. Sci., 29, 143.

Flocks, R. H. (1939). F. Amer. med. Ass., 113, 1466.

Gill, J. R., and Bartter, F. C. (1961). 7. clin. Invest., 40, 716.

Harrison, A. R. (1959). Brit. F. Urol., 31. 398.

Henneman, P. H., Benedict, P. H., Forbes, A. P., and Dudley, H. R (1958). New Engl f. Med., 259, 802.

Hodgkinson, A. (1961). Proc. Ass. clin. Biochem., 1, 52.

Hodgkinson, A., and Pvrah, L. N. (1958). Brit. f. Surg., 46, 10.

Jackson. W. P. U., and Dancaster, C. (1959). F. clin. Endocr., 19, 658.

Knapp. E. L. (1947). 7. clin. Invest., 26, 182.

Knowles, F. (1968). ๆ. med. Lab. Technol., 25, 130.

Nordin, B. E. C., Hodgkinson, A., and Peacock, M. (1967). Clin. Orthop., 52. 293

Peacock, M., Hodgkinson, A., and Nordin, B. E. C. (1967). Brit. med. Y., 3, 469.

Peacock, M., and Nordin, B. E. C. (1968). F. clin. Path. In press.

Phillips, M. J., and Cooke, J. N. C. (1967). Lancet, 1, 1354.

Watson, L., and Dale, N. E., (1966). Clin. Sci., 31, 77. 